\title{
TOWARD A UNIFIED FUNCTIONAL ACCOUNT OF STRUCTURAL FOCUS AND NEGATION IN HUNGARIAN*
}

\author{
ANDRÁS IMRÉNYI \\ Department of Hungarian Linguistics \\ Eötvös Loránd University \\ Múzeum krt. 4/A \\ H-1088 Budapest \\ Hungary \\ imrenyi.andras@gmail.com
}

\begin{abstract}
The goal of this paper is to provide a unified analysis of the function of various types of (structural) focus and the negative particle (used preverbally) in Hungarian. It is argued that the function of these elements (each inducing the inversion of verbal modifier and verb) is best understood with respect to the interpretation assigned to the verbal predicate in different contexts. By treating the verbal predicate as a schematic positive declarative clause (or "proto-statement") in its default interpretation, it becomes possible to define the function of the elements concerned in terms of (i) the kind of relation in which they stand with the proto-statement, (ii) the kind of relation in which the overall symbolic pattern (as a Gestalt) stands with the unmarked positive declarative clause type.
\end{abstract}

Keywords: structural focus, negation, the network model, proto-statement, clause types

\section{Introduction}

For the past three decades, Hungarian syntax has received considerable international attention, largely owing to the work of generative linguists. Not only have these linguists managed to apply a contemporary theory to

* This paper benefited greatly from discussions at the Functional linguistics workshop at Eötvös Loránd University, Budapest with people including Ágnes Hámori, Nóra Kugler, Mária Ladányi, Gábor Tolcsvai Nagy, and Szilárd Tátrai. Also acknowledged are the useful comments of two reviewers, including critical remarks that prompted me to reorganize the material of an earlier version. All remaining errors and shortcomings are my own. 
the description of Hungarian but they have done so in a way which also informed the theory, and stimulated new lines of research (cf. the notion of 'discourse configurational languages' (É. Kiss 1995), or the extensive work on the syntax and semantics of quantifiers by Anna Szabolcsi and others). As a result, whoever writes about Hungarian now has access to a much larger audience than ever before, and for that due credit must be given to the linguists who put their time and talent into the enterprise.

At the same time, it seems that while generative linguists have succeeded in raising and answering a number of model-internal questions about Hungarian (e.g., How are the principles and parameters of UG reflected in the syntax of Hungarian? What $\mathrm{X}^{\prime}$-theoretic structure is to be assigned to Hungarian sentences?), there still remain some core descriptive issues that have eluded them. Ever since Fogarasi's (1838) pioneering work, it has been widely recognized that the key to understanding Hungarian word order is a proper analysis of what happens immediately before the verb; more specifically, why certain elements (viz. wh-expressions, identificational foci, and elements with a restrictive or negative meaning) trigger the inversion of verbal modifier (vm) and verb. A natural question arising in this context is what these elements (socalled "structural foci" and the negative particle) share in their function, something the generative models have either ignored or said little about, despite the category-defining role attached to focus and negation in the distinction between "neutral" and "non-neutral" clauses.

The goal of the present paper is to get closer to an understanding of non-neutral clauses by subsuming structural focus and negation under a single functional account. In section $\mathbf{2}$, I present the basic data, and some aspects of their interpretation in the literature that seem directly relevant to what follows. In section $\mathbf{3}$, I introduce two fundamental assumptions of my alternative proposal: (i) the view of the clause as a network of symbolic relations, and (ii) the default interpretation of the verbal predicate as a schematic positive declarative clause. In section $\mathbf{4}$, I show how the new perspective can be brought to bear on the data. Note that the reanalysis of structural focus and negation will not be possible until several other aspects of the Hungarian clause have been attended to. Finally, summary and conclusions follow in section $\mathbf{5}$.

In terms of theoretical background, I adhere to the basic principles of functional cognitive linguistics, and draw especially heavily on the concepts of Langacker's $(1987 ; 1991)$ cognitive grammar. I also embrace the view of language as a relational network, as most explicitly spelled 
out in the work of Joan Bybee, Sydney Lamb and Richard Hudson. Given this background, the proposal is admittedly more likely to appeal to a functional cognitive audience than a generative one. Having said this, I do hope that the paper will express ideas that many Hungarian native speakers might share, including those committed to different theoretical assumptions as linguists.

\section{Neutral vs. non-neutral clauses:} the basic data and some aspects of their interpretation

In both descriptive and generative accounts of Hungarian word order, it has been customary to distinguish between two major clause types, "neutral" and "non-neutral" (see Kálmán 1985a;b for early descriptive surveys). Although some might consider these terms to be purely descriptive ones not necessarily amenable to theoretical interpretation, Olsvay (2000) and (drawing on Olsvay's work) É. Kiss (2008a) have recently suggested that "non-neutralness" may be explicitly encoded in the phrase structural representation in the form of a functional projection called NonNeutP.

Let us begin with the data, however, and observe what may be regarded as clear-cut cases representing the two clause types. Whereas (1) is a textbook example of neutral clauses, (2a-d) are prototypical instances of the non-neutral type.

(1) János meghívja Marit.

John vm-calls-def.obj Mary-acc

'John invites Mary?'

(2) (a) KIT hív meg János?

who-acc calls vm John

'Whom does John invite?'

(b) MARIT hívja meg János.

Mary-acc calls-def.obj vm John

'It is Mary whom John invites.'

(c) RITKÁN hívja meg János Marit.

rarely calls-def.obj vm John Mary-acc

'Rarely does John invite Mary.' 
(d) Nem hívja meg János Marit. not calls-def.obj vm John Mary-acc 'John does not invite Mary.'

For reasons that need not concern us here, $(2 \mathrm{a}-\mathrm{c})$ and $(2 \mathrm{~d})$ receive rather different treatments in generative models such as É. Kiss (2002). Whereas interrogative, identificational, and restrictive expressions (capitalized in (2a), (2b), and (2c), respectively) are analysed as instances of (structural) focus occupying the specifier position of a Focus Phrase/FP, the sentential negator in (2d) is generally assigned to a functional projection of its own, NegP. ${ }^{1}$ More importantly from our perspective, however, foci and nem 'not' also belong together by playing an essentially similar category-defining role in clausal typology, with 'non-neutralness' sometimes informally equated with the property of 'containing focus and/or negation' (cf. É. Kiss 2008a, 131).

On the side of linguistic form, the three factors below and their correlation seem to provide strong empirical motivation for setting up the two clause types.

(3) (a) Preverbal vs. postverbal positioning of the verbal modifier. This appears to be the strongest factor, perhaps owing to its high level of perceptual salience suggesting functional significance. ${ }^{2}$

(b) Level prosody vs. the presence of a prosodically highly prominent element in the left periphery that "takes away" or substantially reduces the word-initial stress of the elements that follow.

(c) Flexible vs. fixed linear order of the major constituents (the predicate and its arguments and adjuncts).

Although the correlation among these factors is far from being absolute, the examples in (1) and (2) consistently differ on all three counts. The first crucial observation to make about (1) is that the verbal modifier meg immediately precedes the verbal stem hivja 'calls-def.obj' forming a single functional and prosodic unit with it to mean 'invites-def.obj'. Secondly, the sentence has a level prosody; i.e., each of the constituents is assigned approximately the same degree of stress, minor phonetic details

${ }^{1}$ Exceptionally in the generative literature, Surányi (2006) relativizes the distinction between FP and NegP by arguing that negative expressions may also be analysed as foci in certain contexts.

${ }^{2}$ For a similar point about English subject-auxiliary inversion and related phenomena, see Croft $(1994,463)$. 
aside. Thirdly, word order is rather flexible in this type of construction: although the SVO pattern (with a subject-to-topic alignment) seems to be preferred, all other permutations are possible, with only subtle differences in meaning.

By contrast, (2a-d) have the verbal modifier and the verb appearing in the 'inverted order', which can be diagnosed as a marked configuration both psycholinguistically (cf. Pléh 1998, 121-35) and in terms of core grammatical phenomena (e.g., morphological derivation is based on the stem meghiv-, not hiv meg, as meghivás 'invitation' and meghivó 'letter of invitation' illustrate). Relatedly, the clauses contain a prosodically highly prominent element (a focussed expression or the negative particle nem 'not'), which has a profound impact on the prosody of the rest of the sentence, where word-initial stresses tend to be reduced or eliminated completely. Finally, in cases of structural focus at least, the ordering of arguments and adjuncts is not free in the strict sense, as focussing one or another dependent of the verb produces vastly different meanings.

From a functional cognitive perspective, such formal criteria as word order and prosody may play an important part in the discovery of linguistic categories. However, a mere list of formal features cannot exhaust the definition of the category, or account for its cognitive basis; rather, the analysis must make crucial reference to the category's semantic import (cf. Langacker 1987, 12). In other words, the non-neutral clause type has to be interpreted as a symbolic category, associating a particular set of formal (prosodic and/or syntactic) properties with a particular set of functional (semantico-pragmatic) ones, with the category further showing a prototype effect. In line with various construction grammar approaches to language (Langacker's cognitive grammar included), we might argue that a complex syntactic category such as 'non-neutral clause' is not fundamentally different from an individual word or an idiom: they are all symbolic, and only differ in terms of schematicity (cf. Croft-Cruse 2004, 255).

Now, our ability to understand what it means to be a non-neutral clause semantically seems to depend on the capacity to offer a unified functional account of structural foci and the negative particle. After all, it is the presence of these elements (triggering inversion) that differentiates the examples in (2) from the neutral sentence observed in (1). Although I simplify the discussion here by ignoring other instances of non-neutral clauses (e.g., imperative ones such as Hivd meg! 'Invite him/ her!'), this practice is justified by the fact that the examples in $(2 \mathrm{a}-\mathrm{d})$ 
already represent a very heterogeneous class. It seems likely that once we have arrived at a unified functional treatment of these, the analysis will either automatically account for other cases or provide strong clues for doing so.

As I have mentioned above, Olsvay and É. Kiss are among the generative linguists who go farthest in recognizing the non-neutral clause type as a syntactic category. Let us therefore briefly review what they have to say about the category's semantic import, even though their results will probably resist being taken over in their original form into a functional cognitive framework.

Olsvay's research question is similar to mine in that he is looking for a unified functional analysis of what it means to be a (non-)neutral clause. He expresses a firm belief that "there are semantic factors underlying word order typology" (2000, 129; my translation). However, he only provides an answer "at the level of intuitions", suggesting that "if the core idea can be maintained, it may be a challenge left for future research to offer its theoretical elaboration" (idem.). His preliminary solution is couched in event semantics, where affirmative and negative sentences can be distinguished by describing the former with a formula expressing the existence (realization) of an event, and the latter by bringing the whole formula in the scope of a negative operator. Extending the interpretation of negativity to a considerable degree, he goes on to suggest that "non-neutral clauses may be regarded as negative clauses in a broad sense: while neutral clauses only provide information that predicates the existence of something (an event, a set, or an individual), non-neutral clauses also supply information to the effect that the existence of something is denied" (idem.).

Although I probably share the basic intuition that Olsvay expresses, the terms providing information and negativity seem to be used in the passage in potentially problematic ways. While (2d) explicitly encodes negativity, negative information is left for the listener to infer from (2b): under the hypothesis that the speaker conveys "optimally relevant" information in the sense of Sperber-Wilson (1995), identifying Mary as the person John invites (in an effort to answer (2a) as an explicit or implicit question) naturally implies the exclusion of other conceivable options (see Wedgwood 2005 for a related discussion). It seems unclear if the two kinds of "supplying negative information" can be plausibly synthesized, and even if one succeeds in doing so, further difficulties arise such as detecting negativity in imperative clauses. 
Turning now to É. Kiss's work, it is interesting to see that her adoption of Olsvay's syntactic analysis (the NonNeutP) has not been matched by a corresponding ambition to provide a unified semantic analysis of non-neutral clauses. Rather, her recent theory of focus (cf. É. Kiss 2006b; 2008 b) is almost exclusively concerned with accounting for the logical structure and truth conditional interpretation of sentences containing identificational foci (cf. (2b)). Drawing on Higgins (1973) and Huber (2000) she suggests that identificational foci are specificational predicates, "specifying the referential content of the set denoted by the backgrounded post-focus section of the sentence" (É. Kiss 2008b, 287). Under these assumptions, the logico-semantic structure of $(2 \mathrm{~b})$ is essentially identical to that of the pseudo-cleft construction in (4):

(4) Akit János meghív, az Mari.

who-acc John vm-calls that Mary

'Whom John invites is Mary.'

As opposed to Olsvay's preliminary account, this solution is highly explicit; furthermore, it works well for a large proportion of sentences containing identificational focus. Its weakness lies in the fact that it accounts for one type of focussed expression only: it seems impossible, for example, to treat $w h$-words as specificational predicates (not to mention the negative particle). É. Kiss is aware of this problem, and suggests various ways in which her theory could be supplemented to accommodate cases like (2a) and (2c). In É. Kiss (2006b, 183), she remarks:

(5) "As is well-known, certain types of constituents, for example, phrases involving a monotone decreasing quantifier such as kevés 'few', or wh-phrases, are obligatorily "focussed". In the framework under consideration, these types of constituents must be assumed to have an intrinsic $[+\mathrm{F}]$ 'information focus' feature. If a sentence happens to contain more than one $[+F]$ constituent, some auxiliary principle will decide which of them moves to the specifier of PredP [the focus position in this framework]. For example, in a sentence containing both a monotone decreasing quantifier and an interrogative phrase, the interrogative phrase will take precedence over the quantifier because of a principle that in a question the $\mathrm{V}$ and its arguments be in the scope of an interrogative operator."

From our present perspective, the main drawback of this analysis is that it does little to motivate the non-neutral clause type as a semantic category. From the account based on the notion of specificational predicates, it would seem that the uniform syntactic behaviour of the initial elements in (2) is something of a coincidence that does not reflect a comparable 
degree of functional uniformity. Although it is easy to accept this stance in the absence of a better alternative, one would intuitively prefer a unified account if it turns out to be possible.

To summarize this section, I have suggested that the neutral vs. non-neutral clause dichotomy (most explicitly endorsed by Olsvay (2000) and É. Kiss (2008a) in the generative literature) is something that functional cognitive linguists could also recognize (in view of the empirical criteria in (3)), but only if the clause types involved are interpreted as symbolic categories with semantic import. Having briefly reviewed the merits and apparent problems in Olsvay's and É. Kiss's semantic treatments of foci, I now turn to the fundamental assumptions of my own proposal. In section 3.1, I present the view of the clause as a network of symbolic relations (touching briefly on how it compares to the model of clausal structure in transformational generative grammar) before continuing with the interpretation of the verbal predicate in section 3.2.

\section{Fundamental assumptions}

\subsection{The clause as a network of symbolic relations}

All syntacticians agree that the clause is, or has, some kind of structure. However, it is the result of a crucial (if sometimes implicit) theoretical choice how one wishes to conceptualize structure. One common metaphor that seems to be at work in the generative tradition is the following: CLAUSES ARE BUILDINGS. The etymology of the word structure already motivates this, as it goes back to the Latin verb struere 'to build' (cf. also construct). Literally, then, a structure is something that has been built. Although these metaphors look innocuous at first sight, note how the source domain of the metaphor (BUILDING) affects the way the target domain (CLAUSE) is conceptualized in transformational generative grammars:

(6) Clauses ARE BUildings

(a) Buildings are made up of building blocks. The building blocks of the clause are its discrete syntactic constituents (words and phrases), separated by wall-like boundaries $([x[y[z]]])$.

(b) The building blocks of a building fit into certain positions (but not others). Similarly, words and phrases only fit into certain positions/slots. 
(c) Just as the positions which building blocks are about to occupy are "already there", the positions of the clause may have an a priori existence independently of what they are "filled with". This further implies that positions may be left empty. In principle, there is no need to fill every position with a building block.

(d) Positions may also be vacated. A building block may be removed from its original position and built into the structure somewhere else. (This rarely happens with real-world buildings but is possible nevertheless.)

(e) Buildings can be viewed and analysed in isolation from their environments. Similarly, clausal structure can be understood without reference to context.

(f) Generalizations about how buildings are built can be independent from generalizations about how buildings are used. Similarly, the theory of clausal structure (or of a speaker's intuitive knowledge underlying it) can be independent from the theory of how that structure is "put to use" (cf. Chomsky 1986).

In the present paper, clausal structure will be conceptualized in a completely different way, with strong repercussions for the analysis of focus and negation. It will take the form of a network of symbolic relations, where a symbolic relation is understood as a functional relation standing in correspondence to its formal expression. ${ }^{3}$ (Major proponents of a relational network model in functionalism include Bybee 1985; 2001; Hudson 2001; and Lamb 2005). Looked at in this way, the clause does not "get built" by putting together elements of various shapes and sizes; rather, it owes its existence to activation patterns in a network of associations, where semantic links of various types are established and made intersubjectively recognizable by formal means such as word order and morphology.

To appreciate that this is in fact a very traditional view of clausal structure, consider the terms subject and object. These are clearly relational terms in that they only receive their interpretation with respect to a predicative element. Arguably, they are also symbolic, as there are both semantic and formal differences between the subject-of and objectof links (and concomitantly, both semantic and formal parallels between two subjects or two objects). Semantically, Langacker analyses the subject as the primary, and the object as the secondary focal participant of

${ }^{3}$ Cf. Langacker (1987, 81): "A linguistic symbol is bipolar, defined by a semantic structure standing in correspondence to a phonological structure". I depart slightly from Langacker's formulation by focussing on symbolic relations rather than symbolic units, and by replacing the term phonological with a more general one, formal. 
the process (event) denoted by the predicate (cf. Langacker 2001). On the side of linguistic form, the distinction is made recognizable in languages either by word order (cf. English) or morphology (cf. Hungarian). Hence, what we have in both cases is a particular functional relation standing in correspondence to a particular form of expression.

Instead of going through all the implications of the model of the clause as a network of symbolic relations, let me list only those that seem especially relevant to what follows.

(7) (a) Co-interpretation. Under the assumptions of a strictly compositional building block model, each expression has a particular function and the clause as a whole gets interpreted by combining the functional contributions of its elementary parts. By contrast, the network model allows the elements to be "co-interpreted" in the sense that the presence of one expression may crucially influence how the other is to be interpreted, cf. the notion of contextualization in Gumperz (1982), Verschueren (1999, 111-2), Couper-Kuhlen (2003, 16), Tátrai $(2004,491-2)$, etc.

(b) Word order in terms of relations. In the building block model, each expression is said to "occupy" a particular slot-like position in the structure. The network model does not recognize the existence of slots as such; instead, it attempts to define the position of each element with respect to another element (through linear relations such as precedence and adjacency). ${ }^{4}$ For example, the attribute of a subject is typically positioned with respect to the subject, and the subject with respect to the predicate (reflecting the corresponding functional relations). Since we cannot go any further at this point, it may be necessary to assign a special status to the predicate (cf. the notion of the root node in dependency grammar; e.g., in Nivre 2005, 9).

(c) The role of context and usage. Generative grammar tends to view the clause as a discrete unit standing in relative isolation from its context. By contrast, under the network model, the clause may be regarded as the activated part of a larger but partially latent relational network; i.e., the context as it is processed and understood by the interlocutors in the unfolding discourse (cf. Verschueren 1999, 75-114; Tátrai 2004). This suggests a trade-off between the amount of contextually available information and the degree to which information needs to be explicitly encoded/elaborated, cf. Grice's (1975) conversational maxims and the central tenets of Relevance Theory (SperberWilson 1995). Relatedly, the network model assumes no sharp dichotomy between competence and performance: linguistic knowledge pertains to the ability to operate a relational network, and each usage event (cf. Langacker 2000, 9) may have an impact on the organization of knowledge, as most thoroughly explored in Bybee's work.

${ }^{4}$ For similar ideas in different models, see Alberti (2000, 25), Newson-Maunula (2006), etc. 
From this perspective, the unified treatment of structural foci and the negative particle can be attained by investigating their symbolic relation to some other element in the clause. (In effect, 'structural focus' will be understood as a symbolic and relational category just as 'subject' has been argued to be.) This gives rise to the three questions below:

(8) (a) Which expression are foci and nem functionally related to?

(b) How is this functional relation encoded?

(c) What is the nature of this functional relation?

For sentences like $(2 \mathrm{a}-\mathrm{d})$, the obvious candidate is the verbal predicate when it comes to answering (8a). It would be hard to deny that MARIT 'Mary-acc', KIT 'whom', RITKÁN 'rarely' and nem 'not' are all functionally related to meghivja 'invites': the first three are arguments/ adjuncts dependent on the predicate, whereas the negative particle is used to perform a "logical" operation on it. As regards (8b), it is clear that whatever this functional relation is (under the hypothesis that there is a unified way of capturing it), it is encoded by word order and prosody. As already noted in section 2, all these expressions "cause" the verbal modifier to appear in a postverbal position, and all of them "take away" or substantially reduce the word-initial stress of the elements that follow. (Hypothetically, we might suspect that inversion reflects what we have just called 'co-interpretation', i.e., the situation when one expression has a crucial influence on how the other is to be interpreted.) The final question is the most difficult one: just what is the nature of the functional relation holding between foci/nem and the predicate?

To be able to answer (8c), we have to begin by assessing some more basic types of functional relations that can hold between the verbal predicate and other elements of the Hungarian clause, and even before that, we need to assign an interpretation to the predicate itself.

\subsection{The Hungarian verbal predicate as a proto-statement}

In formal syntactic and semantic models based on the building metaphor, the predicate is regarded as a "building block" that needs to be combined with other "building blocks" for a whole sentence to be formed. Under this view, the predicate and the clause are essentially in a part : whole relationship, and the two represent very different types of object. 
In functional cognitive linguistics, a completely different conceptualization is possible. In particular, we can regard the predicate not as an atomic part of the clause but rather as a schematic clause in itself. Although English does not offer the best examples for this (as we shall see shortly, Hungarian fares much better), something along these lines can be deduced from the representation of Heather sings in the following way by Croft-Cruse (2004, 281), based on Langacker's (1987, 304) ideas:

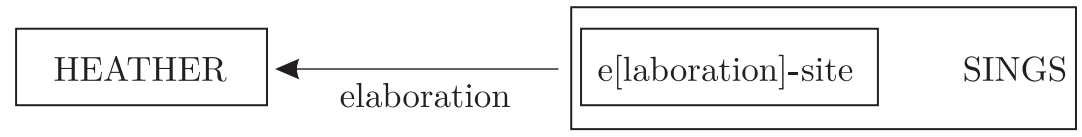

The figure in (9) expresses that "the semantic structure for sings includes a schematic singer as a substructure" (Croft-Cruse 2004, 281). What Heather does semantically is elaborate this substructure, "characteriz[ing] it with greater specificity (i.e., finer precision and detail)", cf. Langacker $(1991,548)$. Now what this seems to entail is that sings is no longer in a simple part: whole relationship with the clause but rather includes (in a schematic, embryonic way) all the information that is more precisely specified by the full sentence, Heather sings. Although Langacker tends to put the emphasis on how the predicate and its arguments (the "component structures") are combined into larger "composite structures" based on their correspondences, and even regards the noun as something semantically autonomous (because its concept does not presuppose other concepts), a more radical interpretation is also possible. Under this view, the noun actually "owes" its existence and semantic role in the clause to the fact that it can elaborate a substructure of a holistic verbal concept/ schematic clause. That this interpretation is not unfaithful to Langacker's intentions is shown by the following passage: "One way to think of correspondences [...] is to view them as a record of the distortions engendered by dissociating an integrated scene into separately symbolized chunks of conceptual content" (Langacker 1987, 279). This clearly presupposes the notion of an integrated scene, which is presumably the semantic structure associated with the predicate.

I hinted above that English did not offer the best examples for the view of the predicate as a schematic clause. This is because English obligatorily requires the presence of at least a pronominal (often "expletive") subject, as demonstrated by the ungrammaticality of * Sings (vs. She sings), and even more strikingly the impossibility of using weather verbs 
in isolation, cf. * Rains (vs. It rains). With transitive verbs, the analytic expression of the object argument is typically also compulsory, except for a small class of verbs whose object arguments may be left implicit, cf. $H e$ is eating. Hence, while the English verb can be justifiably viewed as a semantic clausal core (schematically representing an integrated scene or event), it cannot do the pragmatic job of representing that scene in a fully functional declarative sentence.

Turning now to Hungarian, the key claim I am making is that the Hungarian verbal predicate can and indeed should be viewed as a schematic clause both semantically and pragmatically. Semantically, it is said to be about an event in the broadest sense (including actions, states, etc.) but it is now also seen as having the default pragmatic function of making a statement. To integrate the proposed functions associated with the Hungarian verbal predicate in a single concept, I suggest that it should be regarded as a proto-statement (cf. Imrényi 2007; 2008a;b). The remainder of this section is devoted to enumerating the arguments in support of this claim.

High on the list of empirical arguments is the class of weather verbs and what are misleadingly called 'pro drop' phenomena in the AngloSaxon literature. Unlike English, Hungarian allows single verb forms like those in (10) below to serve as fully functional declarative clauses in themselves. $^{5}$

(10) (a) Esik.

rains

'It rains.'

${ }^{5}$ Cf. Brassai $(1863,11)$ : "[The verb] can perform the function of the sentence in and by itself, without its apprentices, while these latter cannot possibly exist without their master. Esik ['it is raining'], havazik ['it is snowing'], villámlik ['it is lightning'], dörög ['it is thundering'], kiabálnak ['they are shouting'], muzsikál$n a k$ ['they are playing music'], egyél ['eat!'], szaladj ['run!'], etc. fully express in themselves what the speaker wants to convey. And the hearer need not supplement it or replace it by something else, but comes in immediate and complete possession of the concept that the speaker wished to evoke in him. When someone tells me: esik, the whole phenomenon of rain, the darkening of the sky, the fall of raindrops, the dampening of the ground appear in my imagination so fully, even unseen, that the poetic description of a Vörösmarty or Arany [Hungarian poets] could not do better. In this word: kiabálnak, the gasping of mouths, the air and the resulting vibration in the hearer's nerves, the sound itself, are all included, thus the event, the subject and the object are fused into a single word to evoke the desired image" (my translation). 
(b) Énekel.

sings

'He/she sings.'

(c) Meghívja.

vm-calls-def.obj

'He/she invites him/her.'

(10a) is perhaps the easiest to understand: since there are no arguments to be elaborated, the inflected verb alone sufficiently represents the integrated scene of raining in a declarative speech act. In (10b), the third person singular verb form (which is phonologically different from all other forms in its paradigm) marks the presence of a contextually recoverable human subject, obviating the need for analytic expression. Finally, the verb form meghivja in (10c) marks not only the third person subject but also the contextual recoverability ("definiteness") of the object. Obviously the success of communication on uttering (10c) depends on whether or not the hearer is able to uniquely identify the appropriate referents from the context. Hence, while Meghivja is a suitable choice as a reply to (11), it is less likely to introduce a conversation. ${ }^{6}$

(11) Meghívja János Marit?

vm-calls-def.obj John Mary-acc

'Does John invite Mary?'

A second interesting phenomenon that seems to support the view of the Hungarian predicate as a proto-statement is argument incorporation. Whereas in the case of weather verbs, the predicate served as a fully functional clause because there was no argument to be elaborated, here the significant fact is that elaboration goes on within the domain of the predicate. There are two types of argument incorporation to be considered here. The first option is illustrated by (12a), where a second person (therefore epistemically grounded and necessarily recoverable) human object argument is morphologically incorporated into the verb form Meghivlak 'I invite you'. However, there is no need for the predicate to be a single morphological word, and in (12b), the object can be seen as being

${ }^{6}$ Note that English also exceptionally allows the "dropping" of the subject in some finite clauses in richly specified contexts (introduced by a wh-question), cf. A: What did your dad do last weekend? B: Went fishing. Again, Speaker B's utterance would be inappropriate as a conversation starter, suggesting a strong interdependence between syntactic structure and context. (I thank an anonymous reviewer for supplying the example.) 
syntactically incorporated into the predicate (cf. Kiefer 2003). Note that Levelet ir 'He/she is writing a letter' is just as much of a single functional and prosodic unit as Meghivja (and behaves in the same way in inversion patterns). The fact that it is written in two words probably reflects that it is much more transparent both morphosyntactically and semantically. In terms of morphosyntax, it retains the accusative marker $-t$ while semantically its contribution shows little if any sign of idiomaticity.

(12) (a) Meghívlak.

vm-call-1sg(sub)-2sg(obj)

'I invite you.'

(b) Levelet ír.

letter-acc writes

'He/she is writing a letter/engaged in letter-writing.'

The third argument in favour of the analysis concerns the functional equivalence of predicates appearing in the unmarked $v m+\mathrm{V}$ pattern with the positive polarity marker igen 'yes'. There are two contexts in which this equivalence can be ascertained; let us take them in turn.

In reply to the question in (11) above, the patterns in (13) below are all functionally equivalent (communicate the same thing), although full elaboration (13a) is highly marked due to the trade-off between contextually available information and degree of elaboration mentioned in section 3.1.

(13) (a) Meghívja János Marit.

(b) Meghívja.

(c) Meg.

(d) Igen.

(13b-d) can be seen as increasingly reduced versions of (13a). It seems, then, that what is elaboration from one perspective is reduction from another. Meghivja János Marit can be regarded as a more elaborate way of saying Meghivja, but it is also true that Meghivja is a reduced version of Meghivja János Marit. The point is of course that they instantiate the same sentence type (cf. section 4.2.). The use of the verbal modifier $\mathrm{Meg}$ in (13c) in reply to (11) is probably due to general information theoretic factors: given a highly accessible and uniquely relevant predicate consisting of two elements, meg and hivja, the appearance of the first 
leaves only one way of finishing the utterance, which means the second element is redundant.

The other context in which meghivja and igen are functionally equivalent can be illustrated by (14) below, where Annát and Marit serve as contrastive topics.

(14) Annát nem hívja meg János, Marit viszont igen/meghívja.

Ann-acc not calls-def.obj vm John Mary-acc however yes vm-calls-def.obj

'Ann, John does not invite, but Mary, he does.'

Since igen 'yes' can be easily regarded as a proto-statement in the relevant sense (i.e., an extremely schematic positive declarative clause about virtually any uniquely relevant event), its functional equivalence with meghivja 'he/she invites him/her' suggests that the latter is also a protostatement. More specifically, the parallel with igen 'yes' suggests that the marking of declarative illocutionary force is not external to the Hungarian inflected verb (cf. the role of the CP layer in generative grammar) but rather part and parcel of its default interpretation.

A fourth argument is theoretical in nature, and is based on the relational network model of the clause proposed in section 3.1. In such a model, both the function and the distribution of elements are defined in (largely) relational terms. For example, something can only be a subject in relation to a predicate; an attribute can only find its place and role in the clause with respect to some noun it modifies. To avoid circularity, we seem to be in need of an axiomatic element whose function is independently defined. The proto-statement analysis provides this independent definition by linking the function of predicates directly to the speech situation.

The fifth and sixth arguments draw on the concept of developmental plausibility (cf. Lamb 2005, 153), which concerns how such networks "come into being" and develop through time, both in terms of the history of language as a socio-cultural institution and in the mastery of a language by children. It is viable to suppose that the complex networks in the adult language of a Modern Hungarian speaker are the result of gradual evolution from simpler networks; and more specifically, that the predicate as a clausal core may retain "footprints" of this evolution. From a historical point of view, it is worth noting in this respect that the Hungarian verbal suffixes marking person and number are said to come from personal pronouns, arguably suggesting that they were originally subjects in an ancient type of clause (Havas 2003, 17; cf. Givón's 1979 famous phrase 
"Yesterday's syntax is today's morphology"). Under the reasonable assumption that pronouns are among the most ancient nominal expressions in language (as Havas firmly believes), this seems to be a very realistic proposal. If it is accepted, though, then the standard view on (or at least standard jargon about) subject-predicate agreement has to be radically modified. It is not so much the predicate that "agrees with" the subject but rather the other way round: the subject further elaborates a semantic substructure of the predicate that is already schematically elaborated by verbal morphology.

Finally, data from language acquisition also seem to be in accord with the proto-statement account. In particular, it is a widely accepted observation that children typically perform full-blown speech acts (i.e., make statements, requests, etc.) already at the stage of so-called oneword utterances. These one-word speech acts are generally referred to as holophrases (cf., e.g., Tomasello 2003). From this perspective, it seems plausible to hypothesize that while some of the initial holophrases (e.g., Ball for 'Give me the ball') later become re-analysed as parts of more complex patterns, verbs may have the capacity to preserve at least some of their holophrasal properties (although the degree to which they do so may vary from language to language). From the literature on Hungarian language acquisition, Wéber's (e.g., 2009) work seems to be very much in line with my proposal. For example, she notes that the Hungarian verbal paradigm supposedly "agreeing" with the object in terms of definiteness (cf. meghiv valakit 'he/she invites somebody' vs. meghivja öt 'he/she invites him/her') is formed prior to the crystallization of the definite vs. indefinite object distinction in child language. ${ }^{7}$ This may point to the conclusion that not only is subject-predicate agreement verb-governed in Hungarian but also the kind of agreement (whatever cognitive basis it may have) holding between predicates and objects.

On the whole, then, there seems to be substantial converging evidence supporting the analysis of Hungarian predicates as proto-statements in their default interpretation. Although I limit my attention to prototypical verbal predicates (consisting of a verbal modifier and a

7 "Johnny started to use the so-called 'definite object' verbal paradigm without explicitly expressed objects and when the definite article had not even appeared in his language. I have detected that this paradigm is not 'triggered' in child language by the presence of definite objects, but rather with reverse logic, the child adopts these verb forms to refer to objects in the speech situation which are jointly accessible to him and his mother" (Wéber 2009, 152; my translation). 
verb) in this paper, it seems likely that the analysis can be extended to other patterns as well. For example, although Meghivja 'He/she invites him/her' is more naturally regarded as a proto-statement than Meg kellett volna hivnia 'He/she should have invited him/her', which includes various tense, aspect, and modality markers (some of which are analytically expressed), the latter also arguably belongs to the same morphosyntactic paradigm, broadly conceived, as the former. What is important is not so much the terminology but rather the idea that the predicate (be it simple or complex in form) has the default function of a schematic positive declarative clause in Hungarian.

\section{Operations on the proto-statement}

In what follows, I build on the two fundamental assumptions I made in section 3 (the clause as a network of symbolic relations; the verbal predicate as a proto-statement in its default interpretation), and investigate the various types of symbolic relations that can hold between the protostatement and other elements in the clause. In section 4.1, I briefly review elaboration (already mentioned above) and introduce extension as an operation presupposing a certain degree of elaboration. In section 4.2, I finally return to the key concern of this paper, i.e., providing a unified functional account of structural focus and negation.

\subsection{Elaboration and extension}

The most basic relation in which an element can stand with the Hungarian verbal predicate (viewed here as a proto-statement) is elaboration, whereby an element (the "elaborator") characterizes with greater specificity (finer precision and detail) some aspect of the information schematically represented by the predicate. This seems to allow for two possible interpretations. On the one hand, elaboration can be regarded as an operation that some element (e.g., the subject or the object) "performs" on (an elaboration site of) the proto-statement. On the other, we can simply say that two symbolic patterns (Gestalts) - e.g., Meghivja 'He/she invites him/her' and Meghivja János Marit 'John invites Mary' — stand in the relationship of a schematic whole to a more elaborated whole, without necessarily attributing elaboration to a specific element. In general, I incline toward the latter as it allows us to view Igen 'Yes' as a schema with 
respect to Meghivja, and to treat elaboration and reduction as the same thing from two different perspectives, cf. (15) below.

(15) (a) Igen.

(b) Meg.

(c) Meghívja.

elaboration $\downarrow$ reduction

(d) Meghívja Marit.

(e) Meghívja János Marit.

Still, the concept of elaboration as an operation may be retained for $(15 \mathrm{c}-\mathrm{e})$.

As I already noted in section $\mathbf{2}$, the preference is for the subject to be the topic of the sentence, and hence assume preverbal/sentence-initial position (János meghívja Marit). This can be handled easily under the view that the topic role is not in conflict with elaboration but rather represents a function for which only a subset of elaborators can qualify. In the relational network model, the relevant constraints must pertain to particular types of verb-elaborator pairs rather than elaborator classes in themselves. On this basis, the following three relation types can be established:

(16) Type: A particular kind of element is incompatible with a particular kind of predicate.

Example: ${ }^{*}$ Született Péter./ ${ }^{*}$ TOP Péter PREDszületett. was-born Peter

(17) Type: A particular kind of element can serve as an elaborator for a particular kind of predicate but cannot assume topic role.

Example: Született egy gyerek./ ${ }^{*}$ TOPEgy gyerek PREDszületett. was-born a child

'A child was born.'

(18) Type: The elaborator optionally assumes topic role.

Example: Megszületett Péter./ TOPPéter PREDmegszületett.

vm-was-born Peter

'Peter has been given birth.'

These phenomena are widely documented in the generative literature (cf. É. Kiss 2002, 14-20); however, I believe it is the relational cognitive model proposed in this paper that accommodates them the most naturally. With verbs like született, which predicate the coming into being of 
an entity, the entity in question is conceptualized by default as contextually unrecoverable, which accounts for the difference between (16) and (17). Interestingly, the verbal modifier meg turns the predicate into one which may have a contextually recoverable subject argument. This has two consequences: first, the definite argument Péter is compatible with the predicate, and may even assume topic role in the left periphery of the sentence (cf. (18)); second, the new predicate megszületett can serve as a fully functional proto-statement in itself much more naturally (i.e., with fewer contextual restrictions) than született (cf. (19a,b) below). Apart from its use as a reduced form in reply to a yes-no question, született obligatorily requires elaboration by an indefinite argument, which may be egy gyerek 'a child' (postverbally, as in (17)) or the incorporated argument gyerek 'child' used as a verbal modifier (20):

(19) (a) Megszületett. (possibly as a conversation starter)

(b) ?'Született. (only in reply to a yes-no question, cf. (13) above)

(20) Gyerek született.

'A child was born/child-birth has taken place.'

All this suggests that the verbal modifier category has an important role to play in the epistemic grounding of a predication (cf. Langacker 1991, 89-95; Pelyvás 1996), typically marking (the contextual recoverability of) the participants and/or the spatio-temporal relation between the reference event and the speech event (cf. its role as a perfectivizer). Although this seems to be a promising avenue to explore, it is beyond the scope of the present paper.

In terms of defining the topic function more specifically, I concur with Langacker (2001) that the topic can be viewed (at least prototypically) as a reference point. "By serving as an initial focus of attention, the reference point tends to activate an array of associated entities which collectively constitute its dominion" (op.cit., 23). "[A] topic construction expresses a reference point relationship between a thing and a proposition" (ibid., 26). Adapting Langacker's model to the Hungarian data, we can represent János meghivja Marit 'John invites Mary' in the following way (where $\mathrm{C}$ stands for the conceptualizer, D for the dominion opened up by the reference point $\mathrm{R}$, and $\mathrm{T}$ for the target proposition): 
(21) The topic as a reference point

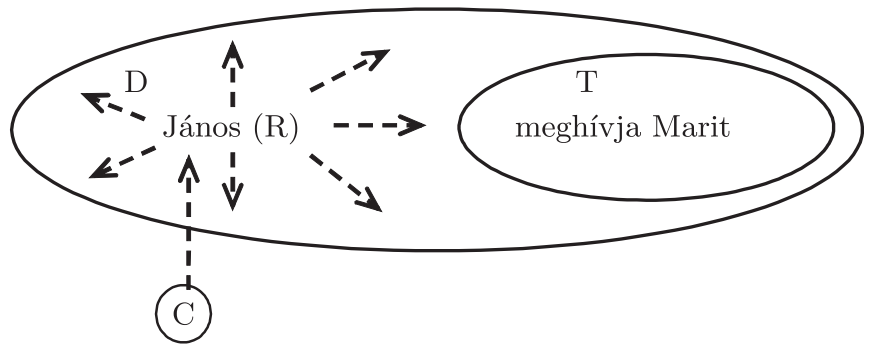

Under the proposed account, János in (21) both elaborates a schematic substructure of meghivja (as its subject argument) and opens up a dominion of which the event denoted by meghivja is also a part. This results in a quasi-symmetrical relationship between the two expressions whereby they mutually evoke each other. Whereas the subject-predicate relationship evoked by the verb concerns the "who-did-what-to-whom" in the sense of Tomasello (1998, xvi), the topic-comment (or reference point-target) relationship evoked by the topic reflects how that who-did-what-to-whom is portrayed in terms of the "windowing of attention" (Talmy 2000, 257309). Understandably, egy gyerek in (18) cannot serve as a reference point: it can only function as a verb elaborator but not as a topic. (For more on the varied interpretations of topic in functional linguistics and their application to Hungarian data, see Tolcsvai Nagy 2008.)

The principal domain of elaboration concerns PARTICIPANTS, and is accounted for primarily by the subject and object arguments. Further important domains include SPACE, TIME, QUANTITY and QUALITY, with strong metaphorical mappings between the first two and the second two. The main difference between the SPACE/TIME domain and the QUANTITY/QUALITY domain is that the latter is more strongly associated with speaker evaluation, comparison, and the like. This is reflected in word order patterns as well, with Hungarian quantifiers and "qualifiers" (adverbs of manner) showing up systematic distributional parallels, cf. Imrényi (2008a). In the unmarked case, both the quantifier sokan 'in a great number' and the qualifier ügyesen 'cleverly' immediately precede the predicate they modify (cf. (22)), although they can also appear postverbally, in the default domain of other types of elaborators. 
(22) (a)

(a) 'Sokan 'megoldották. ('Megoldották'sokan also possible) in-a-great-number vm-solved-it-3pl 'Many people solved it.'

(b) 'Ügyesen'megoldották. cleverly vm-solved-it-3pl

('Megoldották' ügyesen also possible) 'They solved it cleverly.'

The main point to note here is that elaboration never triggers the inversion of verbal modifier and verb, and leaves the predicate's prosody unaffected. This is not surprising: since elaborators only specify aspects of information that are schematically present in the proto-statement, they do not cause any major change in the context for the predicate's interpretation. In other words, the effects of co-interpretation (cf. section 3.1) are fairly negligible.

Note, however, that it is also possible to pronounce (22a,b) above with a prominent pitch accent on the first syllable of sokan/ügyesen and a significantly weaker stress on the proto-statement:

(23) (a) 'Sokan „megoldották.

(b) 'Ügyesen ,megoldották.

This seems to signal an operation that is different from mere elaboration, although it presupposes it. For instance, $(23 \mathrm{~b})$ would be uttered in a context where the proto-statement is known or strongly expected to hold (hence some level of validity is already associated with its substructure for QUALITY), and it is the higher-than-expected degree of the protostatement's fulfilment that is being emphasized. I call this operation extension (in a way related to Langacker's (e.g., 2000) use of the term), ${ }^{8}$ and interpret it as follows:

8 The following passage seems to be especially relevant: "We can reasonably consider categorization to be a special case of comparison, obtaining when the standard represents an established unit and the target (at least originally) is novel. Categorization is most straightforward when there is no discrepancy, i.e., when the standard can be recognized in the target because the latter fully satisfies its specifications. In this case the two structures stand in an elaborative relationship: $[\mathrm{A}] \rightarrow[\mathrm{B}]$. An act of categorization may also register some disparity between the categorizing structure and the target. In this case I speak of extension, indicated with a dashed arrow: $[\mathrm{A}] \rightarrow[\mathrm{B}]$ " (Langacker 2000, 4). In the matter at hand, we are concerned with the categorization of clauses, and a typical instance of elaboration is [Meghivja $] \rightarrow[$ Meghivja Marit $]$, with no discrepancy 
(24) Extension: The expression extends the proto-statement's validity (contextual applicability) to a higher level than previously known or expected. ${ }^{9}$

In terms of the neutral vs. non-neutral clause dichotomy introduced in section 2, clauses containing "extenders" seem to represent an intermediate case. Functionally, extenders are intimately related to elaborators, as in effect they carry out the "further elaboration" of a schematic substructure of the predicate that is assumed to have been elaborated already to a certain degree. However, they are also different from ordinary elaborators, as they account for an incremental update of information (with respect to the preceding context) that therefore resists reduction. For example, (23a) and (23b) are not reducible to Megoldották 'They have solved it' under normal circumstances, as reduction would mean 'downgrading' to a previous state regarding expectations or knowledge. The intermediate status of extenders is also manifested in their syntactico-prosodic behaviour. Although they typically trigger the destressing of the verbal predicate (arguably as a means to reflect that the latter is contextualized as part of the background), they do not cause the verbal modifier to appear postverbally. Hence, they are halfway between elaborators (inducing no change in either word order or prosody) and structural foci (inducing a change in both).

Elements typically performing extension include (i) positive quantifiers and qualifiers of the sokan/ügyesen type (23), (ii) expressions ending with is 'also' (25), (iii) quantifiers and qualifiers expressing a maximal amount or degree (26). Hence, the logically defined quantifier category of generative grammar (cf. É. Kiss 2002, 105-29) can be recast as a cognitive category also including elements from the QUALITY space, cf. Imrényi (2008a).

(25) 'János is ,megoldotta.

John also solved-it-3sg

'John also solved it.'

\begin{abstract}
between specifications. Extension, by contrast, does entail a certain disparity between the categorizing structure and the target, which here results from the mismatch between prior knowledge or expectations on the proto-statement's degree of fulfilment (range of applicability) and an updated information state.

${ }^{9}$ In a similar vein, Kicska (1891) argues that by using the relevant type of expression, "I add something to a smaller extent, manner, number or amount; just as much as required for the extent to be complete" (quoted by É. Kiss 2006a, 444; my translation)
\end{abstract}


(26) (a) 'Mindenki ,megoldotta. everybody solved-it-3sg 'Everybody solved it.'

(b) 'Tökéletesen ,megoldották. perfectly solved-it-3pl 'They solved it perfectly.'

Having discussed elaboration and extension in detail, we are now ready to return to the original issue: what do the structural foci of $(2 \mathrm{a}-\mathrm{c})$ and nem 'not' in (2d) share in their function? In other words, what functional motivation can we provide for the neutral vs. non-neutral clause dichotomy?

\subsection{Restriction. Foci as type markers}

For ease of exposition, I repeat the data of (2) in (27) below.

(27) (a) KIT hív meg János?

who-acc calls vm John

'Whom does John invite?'

(b) MARIT hívja meg János.

Mary-acc calls-def.obj vm John

'It is Mary whom John invites.'

(c) RITKÁN hívja meg János Marit.

rarely calls-def.obj vm John Mary-acc

'Rarely does John invite Mary.'

(d) Nem hívja meg János Marit.

not calls-def.obj vm John Mary-acc

'John does not invite Mary.'

After a long (but necessary) excursus on the predicate's interpretation and the operations of elaboration and extension, we can finally address the question in (8c) above: what is the nature of the functional relation between foci/nem and the verbal predicate? One thing should be immediately clear: this relation cannot be characterized either as elaboration or as extension vis-à-vis the proto-statement meghiv (ja).

The interrogative expression in (27a) is not elaborational because it is precisely the absence of elaboration that it marks: by uttering the sentence, the speaker prototypically expresses that some piece of information 
is crucially missing from his/her knowledge, and requires the listener to supply it. Concomitantly, the sentence also deviates from the unmarked declarative pattern in terms of illocution; however, it is important to observe that a shift in illocutionary force per se does not inevitably trigger inversion. Note the following examples:

(28) (a) ^ Meghívod?

(slightly biased)

vm-call-2sg-def.obj

'Do/will you invite him/her?'

(b) Meghívod -e?

vm-call-2sg-def.obj question

'Do/will you invite him/her?'

(29) (a) Mennyien el jöttek!

in-what-number vm came-3pl

'(Look) how many people have come!'

(b) MENNYIEN jöttek el?

'How many people have come?'

call-imp-2sg-def.obj vm

'Invite him/her!'

(b) Meghívd, különben... (implying a threat)

vm-call-imp-2sg-def.obj or else

'Invite him/her, or else... '

(c) Meghívod!

(issuing a command)

vm-call-2sg-def.obj

'You shall invite him/her!'

The reason why Hungarian yes-no questions typically occur without inversion may be twofold. Firstly, the intonation of (28a), a gradual rise followed by a sharp fall, is enough to mark illocutionary force; similarly, the cliticized interrogative particle $-e$ in $(28 \mathrm{~b})$ can do the same job. Secondly, (28) is in line with the typological and functional observations made by Croft (1994, 467):

"Biased questions often take the form of a declarative plus a tag particle or phrase [...]. In many languages, unbiased interrogatives take the form of a declarative plus an interrogative particle, often sentence-final. Thus, interrogatives, biased or unbiased, are structurally often quite similar to declaratives, which are distinguished because they are unmarked. On the 


\begin{abstract}
function side, biased questions are as much hedged assertions as questions: mutual agreement on the truth of the proposition is hedged until the addressee provides confirmation. In other words, functionally there is a continuum between declaratives, which firmly assert the speaker's belief and expect assent (or at least acknowledgement) from the addressee in response; biased questions, which more weakly assert the speaker's belief and invite explicit assent from the addressee; and neutral questions, which do not assert a speaker's belief and expect a 'filling' in of the indeterminate information from the addressee."
\end{abstract}

As regards (29), the significant observation to make is that while mennyien 'in what number' is followed by the unmarked $\mathrm{vm}+\mathrm{V}$ order in exclamations, it triggers inversion in wh-questions. This follows naturally from my proposal: whereas mennyien in (29a) can be taken to perform extension on the proto-statement eljottek 'they have come' (with the speaker voicing his/her surprise that more people have come than expected), its function is clearly neither elaboration nor extension in (29b), for the reasons discussed above.

Finally, although (30a) shows that the most natural choice for imperatives is the inversion pattern (marking that, for obvious reasons, such clauses do not arise from the elaboration or extension of a proto-statement), it is also possible to bring the form of the imperative closer to declarative clauses, with subtle changes in function. In (30b), the "tension" between using the morphological marker for imperative mood and the word order of declaratives may imply a threat, ${ }^{10}$ while in (30c), the action requested by the speaker is conceptualized as though it were an accomplished fact, leaving no room for refusal. Naturally, whether or not this speech act can be felicitously performed depends on the relative social status of the interlocutors.

To conclude, while illocutionary force seems to be a strong factor in inducing inversion in Hungarian, especially with the "major sentence types" interrogative and imperative, the availability of alternative ways of encoding such functions, as well as the motivated tendency for yes-no questions (and certain forceful commands) to resemble declaratives also make an important contribution. Overall, the negative definition supplied

${ }^{10}$ By using imperative morphology, the speaker implies that the listener can make $p$ happen, yet $\sim p$ is very much an option as far as his/her natural course of action is concerned. At the same time, the declarative word order saliently marks a stronger than usual speaker commitment to $p$. Since such salient marking is normally not expected to be necessary, this implies a possible conflict in preferences that may be perceived as a (face) threat.

Acta Linguistica Hungarica 56, 2009 
at the outset seems to be a useful one (cf. (29)): wh-expressions tend to trigger inversion in precisely those cases when they perform neither elaboration nor extension on the proto-statement.

Turning now to (27b), the following examples are worth comparing:

(31) (a) 'Meghívja 'Marit. 'He/she invites Mary.'

(b) 'Marit is , meghívja. 'He/she invites Mary, too.'

(c) MARIT hívja meg. 'It is Mary whom he/she invites.'

In (31a), Marit simply elaborates a schematic substructure of the protostatement meghivja. In (31b), it is used to extend the proto-statement's range of contextual applicability to a higher level than previously known or expected. The sentence presupposes that the PARTICIPANTS substructure of meghivja already includes a contextually recoverable set of specific referents and adds Mary to that set. By contrast, (31c) amounts to the restriction of a contextually relevant set (e.g., one evoked by a wh-question): it identifies Mary as the relevant person John invites and by doing so, implies the exclusion of other conceivable options (cf. the notion of "exclusion by identification" in Kenesei 1986). This is not unlike the generative interpretation assigned to identificational foci by É. Kiss and others but has the advantage of providing the grounds for a unified analysis of focus and negation in Hungarian. From my proposal's perspective, what is important about identificational foci is that they perform neither elaboration nor extension on the proto-statement. Hence, MARIT hivja meg cannot be reduced to Meghívja in any context, regardless of how much information is shared by the speaker and the listener - which is true about sentences with other types of structural focus as well. ${ }^{11}$

Moving on to the analysis of (27c), consider the "minimal pair" in (32) below.

${ }^{11}$ As a reviewer has correctly pointed out, identificational foci "do more than 'restrict' a statement: they make a statement", which is also suggested by the possibility to reduce (2b) to MARIT in the context of replying to (2a). However, as my aim here is to provide a unified functional account of various types of focussed expressions, I necessarily ignore some of the features which are peculiar to a given type. 
(32) (a) Néha meghívja János Marit. sometimes vm-calls-def.obj John Mary-acc 'Sometimes, John invites Mary.'

(b) RITKÁN hívja meg János Marit. 'Rarely does John invite Mary.'

From an objective, "God's eye" perspective, both (32a) and (32b) express the same thing: that the event of John inviting Mary occurs at a low level of frequency. The functional difference between the two reflects how the speaker construes/evaluates the situation: while (32a) suggests that $p$ does happen (if only $n$ times), (32b) restricts the validity of the protostatement ( $p$ only happens $n$ times). As a result, while (32a) is in principle reducible to Meghívja János Marit without significantly distorting the intended message, (32b) is not. ${ }^{12}$ Whereas with identificational focus, restriction seemed to presuppose the concept of a set, $(32 \mathrm{a}, \mathrm{b})$ show that it can also reflect a simple choice made by the speaker that the glass is half empty rather than half full. The natural endpoint of such negative evaluation is of course full negation, as illustrated by (27d) above.

The fact that restriction is expressed by inversion and the loss of stress on the predicate may be seen as inherently iconic. Contextualized by a focus or the negative particle, the predicate can no longer serve to "represent" the full clause, as the latter can no longer be reduced to it. The iconic nature of stress patterns is hardly controversial from a functional cognitive perspective (with restricted function marked by diminished prosodic prominence). However, inversion seems to be no less iconic when one considers the connotation commonly associated with expressions such as upside down, putting the cart before the horse, etc. It seems that humans typically perceive and conceive of entities, actions, etc. in the world as having a normal/natural realization, which guarantees their proper functioning, successful accomplishment, etc. By contrast, when something is turned upside down, the chances of it not functioning normally are remarkably high. Similarly, the inversion of the elements of a prototypical Hungarian predicate may signal that it is not to be interpreted in the usual way (as a schematic positive declarative clause) because of the overriding effects of context.

Finally, recall that in section 4.1, I mentioned two possible ways of interpreting elaboration: (i) as an operation an element performs on (an

${ }^{12}$ For a similar analysis of negative adverbials and their property of triggering inversion, see Péter (2008). 
elaboration site of) the proto-statement, (ii) as a relationship between two symbolic patterns (Gestalts). By the same token, what is introduced here as restriction (or more generally, something that is neither elaboration nor extension) can be regarded as an operation performed by expressions such as KIT, MARIT, RITKÁN, and nem, but it also has important clause-level repercussions.

Specifically, the broad functional definition we can now give to non-neutral clauses is that they represent a marked sentence type against the unmarked positive declarative type predicating the proto-statement. Not surprisingly, there are two major paths of deviation from the unmarked: (i) a shift in polarity (when a sentence is negative rather than positive), (ii) a shift in illocution (when a sentence does not predicate the proto-statement, either because it does not predicate anything or because it predicates something else, cf. the identification performed by (2b)). More significantly, however, the clause type may also receive a narrower, symbolic definition, based on perceived correlations between form and function. In this narrower sense, the set of non-neutral clauses only includes those sentences which signal deviation from the unmarked positive declarative by the inverted order of verbal modifier and verb, and in which inversion has precisely this function. (Of course, when the verbal modifier is absent, inversion is neutralized, but this need not prevent us from categorizing the clauses involved as non-neutral, if inversion can be elicited in a paraphrase with an appropriate predicate.) This yields the classification shown in (33). ${ }^{13}$

The proposal is in line with Croft's observation that "the positive/ negative parameter [...] is comparable in typological significance to the declarative-interrogative-imperative speech act distinction" (Croft 1994, 466). Furthermore, it also motivates it by the assumption of a positive declarative core as a categorizing schema for a wide range of expressions.

13 The significance of combining the sentence type based analysis with the negative definition proposed earlier on is that it helps motivate why markers of epistemic modality such as feltehetôleg 'presumably' are not focussed, despite the fact that they are not naturally treated (in my view) as either elaborators or extenders. This is because they are not type changing: János feltehetöleg meghívja Marit 'Presumably, John invites (will invite) Mary' belongs to the unmarked positive declarative class just as much as János meghívja Marit 'John invites (will invite) Mary' does. For a more detailed discussion of how these expressions may be analysed in the model, see Kugler (2009). 
(33)

\begin{tabular}{|c|c|c|}
\hline & Type & Example \\
\hline & Positive declarative (unmarked) & János meghívja Marit. \\
\hline \multirow{4}{*}{ 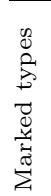 } & Jै Open interrogative & KIT hív meg János? \\
\hline & Identificational & MARIT hívja meg János. \\
\hline & Negative & RITKÁN/Nem hívja meg János Marit. \\
\hline & Imperative & Hivd meg! \\
\hline
\end{tabular}

To conclude, there seem to be two complementary ways of subsuming "structural foci" and the sentential negator under a single functional account. From the proto-statement's perspective, they are restrictive (contextualizing the predicate in such a way that it cannot "represent" the full clause); more generally, they belong to the class that performs neither elaboration nor extension. However, they can also be regarded as type shifting expressions from the full clause's perspective, as they represent major paths of deviation from the unmarked positive declarative clause type predicating the proto-statement. Still, it is important to emphasize that it is the proto-statement's perspective that offers a better starting point for providing a unified functional analysis of Hungarian structural focus and negation.

\section{Summary}

The goal of this paper was to provide a unified functional account of Hungarian structural focus and negation in an effort to reach a better understanding of the neutral vs. non-neutral clause dichotomy. Endorsing the intuition expressed in Olsvay (2000) and É. Kiss (2008a) about the distinction itself, I was looking for a way to characterize the non-neutral clause type as a symbolic category with semantic import.

The proposal presented in section $\mathbf{4}$ crucially relied on the theoretical decisions made in section $\mathbf{3}$. Here, the "building block" model of clausal structure had been replaced by a model in which the clause was regarded as a network of symbolic relations (functional relations standing in correspondence to their formal expressions). This, along with the Hungarian verbal predicate's interpretation (by default) as a schematic positive declarative clause or proto-statement, paved the way for a new analysis of focus and negation. Foci and nem 'not' were seen as contextualizing elements performing restriction (neither elaboration nor extension) on 
the proto-statement. In line with Croft (1994), I also suggested that from the perspective of the overall clause, these elements could be classified as type shifting expressions, since they introduced marked sentence types in opposition to the unmarked positive declarative.

Needless to say, further work is needed to test the limits of the model (i.e., to see what it can and what it cannot explain), and several refinements may also be necessary. However, I do believe that a unified functional analysis of focus and negation is something that all models of Hungarian syntax should strive to achieve, and hope that some of the ideas in this paper may bring us closer to that goal.

\section{References}

Alberti, Gábor 2000. Lifelong Discourse Representation Structures. In: Gothenburg Papers in Computational Linguistics 00-5 : 13-20.

Brassai, Sámuel 1863. A magyar mondat (II) [The Hungarian sentence, part 2]. In: Akadémiai Értesítő 3:3-127.

Bybee, Joan L. 1985. Morphology. A study of the relation between meaning and form. John Benjamins, Amsterdam \& Philadelphia.

Bybee, Joan L. 2001. Phonology and language use (Cambridge Studies in Linguistics 94). Cambridge University Press, Cambridge.

Chomsky, Noam 1986. Knowledge of language: Its nature, origin and use. Praeger, New York.

Couper-Kuhlen, Elizabeth 2003. Intonation and discourse: Current views from within. In: Deborah Schiffrin-Heidi E. Hamilton (eds): The handbook of discourse analysis, 14-34. Blackwell, Malden MA \& Oxford.

Croft, William 1994. Speech act classification, language typology and cognition. In: Savas L. Tsohatzidis (ed.): Foundations of speech act theory: Philosophical and linguistic perspectives, 460-77. Routledge, London \& New York.

Croft, William-David Alan Cruse 2004. Cognitive linguistics. Cambridge University Press, Cambridge.

É. Kiss, Katalin (ed.) 1995. Discourse configurational languages. Oxford University Press, Oxford.

É. Kiss, Katalin 2002. The syntax of Hungarian. Cambridge University Press, Cambridge.

É. Kiss, Katalin 2006a. Focussing as predication. In: Valéria Molnár-Susanne Winkler (eds): The architecture of focus, 169-93. Mouton de Gruyter, Berlin \& New York.

É. Kiss, Katalin 2006b. Jól megoldottuk? Rosszul oldottuk meg? Az összefoglaló és a kirekesztő kifejezést tartalmazó mondatok szórendjének magyarázata [Have we solved it correctly? Have we solved it incorrectly? Explaining the word order of inclusive and exclusive expressions]. In: Magyar Nyelv 102:442-59. 
É. Kiss, Katalin 2008a. Tagadás vagy egyeztetés? A senki, semmi típusú névmások szórendi helye, jelentése és hangsúlyozása [Negation or concord? The word order, interpretation and prosody of se-pronouns]. In: Magyar Nyelv 104:129-43.

É. Kiss, Katalin 2008b. Topic and focus: Two structural positions associated with logical functions in the left periphery of the Hungarian sentence. In: Acta Linguistica Hungarica 55:287-96.

Fogarasi, János 1838. Euréka [Heureka]. In: Athenaeum 3:193-8, 241-9, 289-97.

Givón, Talmy 1979. On understanding grammar. Academic Press, New York.

Grice, H. Paul 1975. Logic and conversation. In: Peter Cole-Jerry L. Morgan (eds): Syntax and semantics, vol. 3: Speech acts, 41-58. Academic Press, New York.

Gumperz, John 1982. Discourse strategies. Cambridge University Press, Cambridge.

Havas, Ferenc 2003. A tárgy tárgyában. Mondattipológiai fontolgatások [On the subject matter of objects. A study in clausal typology]. In: Beatrix Oszkó-Mária Sipos (eds): Budapesti Uráli Mühely III, 7-44. MTA Nyelvtudományi Intézet, Budapest.

Higgins, Roger F. 1973. The pseudo-cleft construction in English. Doctoral dissertation, MIT.

Huber, Stefan 2000. Es-Clefts und det-Clefts. Zur Syntax, Semantik und Informationsstruktur von Spaltsätzen im Deutschen und Schwedischen. Almqvist \& Wiksell, Stockholm.

Hudson, Richard 2001. Language as a cognitive network. In: Simonsen-Endresen (2001, 49-72).

Imrényi, András 2007. A magyar szórend kísérleti modelljei 2. Tartományok és viszonyok a magyar mondatban [Experimental models of Hungarian word order 2. Domains and relations in the Hungarian clause]. In: Magyar Nyelvőr 131:430-51.

Imrényi, András 2008a. Quantifiers and qualifiers: A unified approach. In: The Even Yearbook 8. (http://seas3.elte.hu/delg/publications/even/2008/08im.pdf)

Imrényi, András 2008b. Szerkezeti fókusz - pragmatikai típusjelölés? [Structural focus - pragmatic type marking?]. In: Általános Nyelvészeti Tanulmányok 22 : 203-39.

Kálmán, László 1985a. Word order in neutral sentences. In: Kenesei (1985, 13-23).

Kálmán, László 1985b. Word order in non-neutral sentences. In: Kenesei (1985, 25-37).

Kenesei, István (ed.) 1985. Approaches to Hungarian 1 (Data and descriptions). JATE, Szeged.

Kenesei, István 1986. On the logic of Hungarian word order. In: Werner AbrahamSjaak de Meij (eds): Topic, focus, and configurationality, 143-59. John Benjamins, Amsterdam.

Keszler, Borbála - Szilárd Tátrai (eds) 2009. Diskurzus a grammatikában - grammatika a diskurzusban [Discourse in grammar - grammar in discourse]. Tinta Könyvkiadó, Budapest.

Kicska, Emil 1891. Hangsúly és szórend [Stress and word order]. In: Magyar Nyelvőr $20: 292-98$.

Kiefer, Ferenc 2003. A kétféle igemódosítóról [On the two types of verbal modifier]. In: Nyelvtudományi Közlemények $100: 177-86$.

Acta Linguistica Hungarica 56, 2009 
Kugler, Nóra 2009. A módosítószók funkcionális megközelítése [A functional approach to modal adverbs]. In: Keszler - Tátrai (2009, 140-8).

Lamb, Sydney 2005. Language and brain: When experiments are unfeasible, you have to think harder. In: Linguistics and the Human Science 1:151-76.

Langacker, Ronald W. 1987. Foundations of cognitive grammar, Vol. 1: Theoretical prerequisites. Stanford University Press, Stanford.

Langacker, Ronald W. 1991. Foundations of cognitive grammar, Vol. 2: Descriptive application. Stanford University Press, Stanford.

Langacker, Ronald W. 2000. A dynamic usage-based model. In: Michael BarlowSuzanne Kemmer (eds): Usage-based models of language, 1-63. CSLI Publications, Stanford.

Langacker, Ronald W. 2001. Topic, subject, and possessor. In: Simonsen-Endresen (2001, 11-48).

Newson, Mark - Vili Maunula 2006. Whose side is the focus on? In: The Even Yearbook 7. (http://seas3.elte.hu/delg/publications/even/2006/06nm.pdf)

Nivre, Joakim 2005. Dependency grammar and dependency parsing (MSI Report 05133). Technical report, Växjö University. (http://vxu.se/msi/ nnivre/papers/05133.pdf)

Olsvay, Csaba 2000. Formális jegyek egyeztetése a magyar nemsemleges mondatokban [The checking of agreement features in Hungarian non-neutral sentences]. In: László Büky-Márta Maleczki (eds): A mai magyar nyelv leírásának újabb módszerei IV [Recent methods in the description of Contemporary Hungarian 4], 119-52. JATEPress, Szeged.

Pelyvás, Péter 1996. Subjectivity in English: Generative grammar versus the cognitive theory of epistemic grounding. Peter Lang, Frankfurt am Main.

Péter, Mihály 2008. A magyar aspektusról - más aspektusból [On Hungarian aspect from another aspect]. In: Magyar Nyelv 104:1-11.

Pléh, Csaba 1998. A mondatmegértés a magyar nyelvben [Sentence interpretation in Hungarian]. Osiris Kiadó, Budapest.

Simonsen, Hanne Gram - Rolf Theil Endresen (eds) 2001. A cognitive approach to the verb. Morphological and constructional perspectives. Mouton de Gruyter, Berlin \& New York.

Sperber, Dan-Deirdre Wilson 1995. Relevance: Communication and cognition. Second edition. Blackwell, Cambridge MA \& Oxford.

Surányi, Balázs 2006. Quantification and focus in negative concord. In: Lingua 116 : 272-313.

Talmy, Leonard 2000. Toward a cognitive semantics. Vols I-II. MIT Press, Cambridge MA.

Tátrai, Szilárd 2004. A kontextus fogalmáról [On the notion of context]. In: Magyar Nyelvör 128: 479-94.

Tolcsvai Nagy, Gábor 2008. Topik, információfolyam, szórend [Topic, information flow, and word order]. In: Általános Nyelvészeti Tanulmányok 22 : 455-500.

Tomasello, Michael (ed.) 1998. The new psychology of language. Cognitive and functional approaches to language structure. Lawrence Erlbaum Associates, Mahwah NJ. 
Tomasello, Michael 2003. Constructing a language. A language based theory of language acquisition. Harvard University Press, Cambridge MA.

Verschueren, Jef 1999. Understanding pragmatics. Arnold, London.

Wéber, Katalin 2009. Beszéd hangról hangra: mentális fonotéka [Sound by sound: The phonoteque of the mind]. In: Keszler - Tátrai (2009, 149-59).

Wedgwood, Daniel 2005. Shifting the focus. From static structures to the dynamics of interpretation. Elsevier, Amsterdam. 